慶應義塾大学学術情報リポジトリ

Keio Associated Repository of Academic resouces

\begin{tabular}{|c|l|}
\hline Title & $\begin{array}{l}\text { Changes of glutathione and taurine concentrations in lenses of rat eyes induced by galactose- } \\
\text { cataract formation or ageing }\end{array}$ \\
\hline Sub Title & \\
\hline Author & $\begin{array}{l}\text { 粕谷, 美南子(Kasuya, Minako) } \\
\text { 糸井, 素—(Itoi, Motokazu) } \\
\text { 小林, 静子(Kobayashi, Shizuko) } \\
\text { 須永, 博之(Sunaga, Hiroyuki) } \\
\text { 鈴木, 和夫(Suzuki, Kazuo) }\end{array}$ \\
\hline Publisher & 共立薬科大学 \\
\hline Publication year & 1992 \\
\hline Jtitle & $\begin{array}{l}\text { 共立薬科大学研究年報 (The annual report of the Kyoritsu College of } \\
\text { Pharmacy). No.37 (1992.),p.60-60 }\end{array}$ \\
\hline JaLC DOI & \\
\hline Abstract & \\
\hline Notes & 抄録 \\
\hline Genre & Technical Report \\
\hline URL & https://koara.lib.keio.ac.jp/xoonips/modules/xoonips/detail.php?koara_id=AN00062898-0000003 \\
\hline $7-0060$ \\
\hline
\end{tabular}

慶應義塾大学学術情報リポジトリ(KOARA)に掲載されているコンテンツの著作権は、それぞれの著作者、学会または出版社/発行者に帰属し、その権利は著作権法によって 保護されています。引用にあたっては、著作権法を遵守してご利用ください。

The copyrights of content available on the KeiO Associated Repository of Academic resources (KOARA) belong to the respective authors, academic societies, or publishers/issuers, and these rights are protected by the Japanese Copyright Act. When quoting the content, please follow the Japanese copyright act. 


\title{
Changes of Glutathione and Taurine Concentrations in Lenses of Rat Eyes induced by Galactose-cataract Formation or Ageing
}

\author{
Minako KaSuYA*, Motokazu ItoI*, Shizuko Kobayashi, Hiroyuki SunagA** \\ and Kazuo T. SUzUKI** \\ 粕谷美南子*, 系井素一*, 小林静子, 須永博之**, 鈴木和夫**
}

Sulfur-containing compounds in the lens were studied in relation to galactose cataract formation. Female Wistar rats were fed a $35 \%$ galactose diet and the changes in lens sulfur concentration and its distribution on a gel filtration column were compared with age-related changes. Concentration of sulfur in the whole lens decreased with time. A low constant level was attained on the fifth day of the galactose diet. A decrease of sulfur concentration in the soluble fraction of the lens paralleled that of the whole lens which was correlated with the decrease of glutathione and taurine concentrations on a gel flltration column by high-performance liquid chromatography-inductively coupled argon plasma atomic emission spectrometry (HPLC-ICP). Concentration of magesium in the lens decreased after the fifth day, while the ratio of sodium to potassium increased. These changes in sulfur-containing compounds and metals were observed prior to the onset of cataract formation.

* (財) 白内障研究所,

** 国立環境研究所 Exp. Eye Res.54（1992），49-53.に発表. 